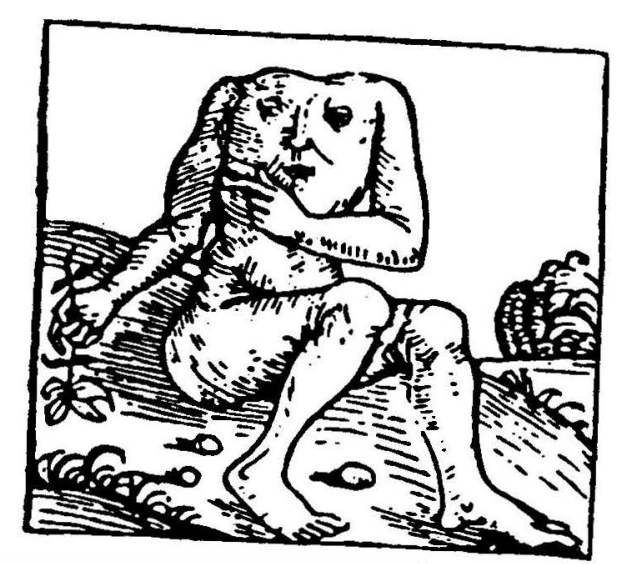

Blemmya

\title{
Hvad er det episke teater?
}

\author{
WALTER BENJAMIN
}

\section{Det afslappede publikum}

"Intet er skønnere end at ligge på sofaen og læse en roman, “ hedder det hos en af forrige århundredes epikere. Dermed er antydet, hvor stor afslapning den nydende kan opnå i mødet med et fortællende værk. Den forestilling, man gør sig om en, der overværer et drama, plejer at være nogenlunde den modsatte. Man tænker på en mand, der med alle fibre, anspændt, følger et hændelsesforløb. Begrebet det episke teater (som Brecht har skabt som teoretiker for sin egen praksis) antyder frem for alt, at dette teater ønsker sig et afslappet publikum, der følger handlingen anspændt. Det vil ganske vist altid optræde som kollektiv, og det adskiller det fra den læsende, der er alene med sin tekst. Desuden vil dette publikum, netop som kollektiv, mest se sig foranlediget til prompte stillingtagen. Men denne stillingtagen, forestiller Brecht sig, bør være overlagt, og dermed afslappet, kort sagt interesserede menneskers stillingtagen. En dobbelt genstand er forudset til deres deltagelse. For det første hændelsesforløbene; de skal være af en sådan art, at de på afgørende steder kan kontrolleres ud fra publikums erfaring. For det andet opførelsen; ifølge sin artistiske armatur skal den udformes, så den er gennemsigtig. (Denne udformning står i fuldkommen modsætning til „ukunstletheden“; den forudsætter i virkeligheden kunstforstand og skarpsindighed hos sceneinstruktøren). Det episke teater henvender sig til interesserede, „,som ikke tænker uden grund". Brecht taber ikke masserne af syne, deres betingede brug af tænkningen er det vel, der skal dækkes med denne formel. I bestræbelsen på at interessere publikum fagkyndigt i te- 

atret, men aldeles ikke via den blotte dannelse, sætter en politisk
vilje sig igennem.

\section{Fablen}

Det episke teater skal "berøve scenen dens stoflige sensation”. Derfor vil en gammel fabel ofte yde det mere end en ny. Brecht forelagde sig selv spørgsmålet, om ikke de hændelsesforløb, det episke teater fremstiller, burde være kendt i forvejen. Det ville da forholde sig til fablen som balletmesteren til sin elev; hans forste opgave var at løsne hendes led til grænsen af det mulige. (Det kinesiske teater bærer sig faktisk sådan ad, Brecht har i „Afstandsskabende effekter („Verfremdungs“-effekter) i den kinesiske skuespilkunst", [Om tidens teater, 1960], gjort rede for, hvad han skylder det). Skal teatret holde udkig efter kendte begivenheder "ville historiske hændelser i første omgang egne sig bedst". Deres episke stræk gennem spillemåden, plakaterne og de skrift lige islæt går ud på at drive sensationskarakteren ud af dem.

I sit seneste stykke gør Brecht således Galileis liv til genstand for behandling. Brecht fremstiller primært Galilei som en stor lærer. Galilei lærer ikke bare en ny fysik, han lærer den på en ny måde. Eksperimentet bliver i hans hænder ikke bare en erobring af videnskaben men af pædagogikken. Hovedvægten i dette stykke ligger ikke på Galileis tilbagekaldelse. Tværtimod er det virkelig episke hændelsesforløb at finde i det, der fremgår af teksten over det næstsidste billede: „1633-1642. Som inkvisitionens fange fortsætter Galilei sine videnskabelige arbejder helt til sin død. Det lykkes ham at smugle sit hovedværk ud af Italien."

Dette teater er på en helt anden måde end det tragiske i pagt med tidsforløbet. Fordi spændingen i mindre grad gælder udfaldet end de enkelte begivenheder, kan det spænde over de største tidsrum. (På samme måde skete det i sin tid i mysteriespillet. Dramaturgien i „Ødipus" eller „Vildanden" er modpolen til den episke).

\section{Den utragiske helt}

Franskmændenes klassiske teater gjorde mellem spillerne plads til standspersonerne, som havde deres lænestole på den åbne
Os forekommer det malplaceret. Lige sa malplaceret ville scene. Os for det begreb om "det dramatiske" vi kender så det synes, ifre å scenen en godt fra teatret, at tiljoperson som nøgtern iagttager, „den tæn-

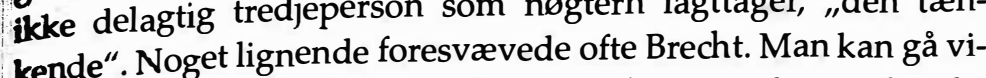
dere og sige, at Brecht foretog forsøget på at gøre den tænkende, a den vise til dramatisk helt. Og netop herudfra kan man defija den vise til dramater som episk. Dette forsøg blev drevet videst i figuren Galy Gay, pakkeren. Galy Gay, helten i stykket Mann ist Mann, er ikke andet end en skueplads for de modsigelser, der udgør vort samfund. Måske er det ikke for dristigt i Brechts ånd at betragte den vise som den fuldkomne skueplads for dets dialektik. I hvert fald er Galy Gay en vismand. $\mathrm{Nu}$ indså allerede Platon meget vel det udramatiske ved det højeste menneske, den vise. I sine dialoger førte han dette menneske frem til dramaets tærskel - i Faidon til passionsspillets tærskel. Den middelalderlige Kristus, der, som vi finder det hos kirkefædrene, tillige repræsenterede den vise, er den utragiske helt par excellence. Men det verdslige drama i vesten er heller aldrig ophørt med at søge den utragiske helt. Dette drama har, ofte i konflikt med sine teoretikere, på stadig nye måder adskilt sig fra tragikkens autentiske skikkelse, det vil sige den græske. Den vigtige, men dårligt markerede vej (der her kan stå som billede på en tradition) gik i middelalderen over Hroswitha og mysterierne; i barokken over Gryphius og Calderón. Senere aftegnede den sig hos Lenz og Grabbe og til sidst hos Strindberg. Shakespeareske optrin står som monumenter langs dens kant, og Goethe krydsede den $\mathrm{i}$ anden del af Faust. Det er en europæisk vej, men også en tysk. Hvis man ellers kan tale om en vej og ikke snarere om en smugler- og snigsti, ad hvilken det middelalderlige og barokke dramas arv har nået os. Denne bjergsti, hvor vildsom og tilgroet den end er, træeder i nutiden for dagens lys i Brechts dramaer.

\section{Afbrydelsen}

Brecht lader sit teater fremtræde som episk på baggrund af det $\mathrm{i}$ snævrere forstand dramatiske, hvis teori Aristoteles formule- 
rede. Derfor indfører Brecht den dertilsvarende dramaturgi som den ikke-aristoteliske, ligesom Riemann indførte en ikke-euklidisk geometri. Denne analogi kan eventuelt tydeliggøre, at det ikke drejer sig om et konkurrenceforhold mellem teatrets diskutable former. Hos Riemann bortfaldt parallelaksiomet. Hvad der faldt væk i den brechtske dramatik var den aristoteliske katarsis, affekternes bortkørsel ved indføling i heltens bevægende skæbne.

Den afslappede interesse hos det publikum, som det episke teaters opførelser er tiltænkt, har netop sin særart i det forhold, at der næppe appelleres til tilskuernes indfølingsevne. Det episke teaters kunst er tværtimod at fremkalde forbavselse i stedet for indføling. Formelagtigt udtrykt: i stedet for at føle sig ind i helten skal publikum tværtimod lære at forbavses over de forhold, han bevæger sig $\mathrm{i}$.

Det episke teater, mener Brecht, skal ikke så meget udfolde handlinger som fremstille tilstande. Fremstilling er imidlertid ikke gengivelse i de naturalistiske teoretikeres forstand. Tværtimod drejer det sig frem for alt om at opdage tilstandene. (Man kunne lige så vel sige: at fremmedgøre dem). Denne opdagelse (fremmed gørelse) af tilstande foregår ved hjælp af afbrydelsen af forløb. Det mest primitive eksempel: en familiescene. Pludselig træder der en fremmed ind. Konen var netop i begreb med at gribe en bronzefigur for at kyle den efter datteren; faderen $i$ begreb med at åbne vinduet for at tilkalde en betjent. I dette øjeblik kommer den fremmede til syne i døren. "Tableau" - som man plejede at sige omkring 1900. Det vil sige: Den fremmede konfronteres med tilstanden; forvildede miner, åbent vindue, ødelagt inventar. Der findes imidlertid et blik, for hvilket selv vantere scener af det borgerlige liv ikke tager sig stort anderledes ud.

\section{Den citerbare gestus}

„Hver sætnings virkning," hedder det i et dramaturgisk læredigt af Brecht, „blev afventet og blotlagt. Og der blev ventet, indtil mængden havd e lagt sætningerne i vægtskålen." Kort sagt, spillet blev afbrudt. Her må man igen gribe videre og erindre sig, at afbrydelsen er en af de fundamentale fremgangsmåder $i$ al form- givning. Den rækker langt ud over kunstens område. Den ligger, grem, til grund for citatet. At cifor bare at traks indbefatter: at afbryde dens sammenhæng. Derfor er tere en tekstindbefater: at a det vel forståeligt, at det episke teater, der er baseret pă afbryde sen, er et i specifik forstand citerbart teater. At dets tekster kan citeres er ikke noget særligt. Anderledes forholder det sig med de gestus, der er på deres plads i spillets forløb.

At gøre gestus citerbare" er en af det episke teaters væsentlige præstationer. Skuespilleren skal kunne spærre sine gebærder ligesom en sætter kan spærre ordene. Denne effekt kan for eksempel opnås ved, at skuespilleren selv citerer sin gestus på sceSåledes iagttog man i Happy End, hvordan Carola Neher i rollen som kvindelig Frelsens Hær-sergent, der i en sømandsknejpe, for at skaffe proselytter, havde sunget en sang, der passede bedre dér end i kirken, måtte citere denne sang og den gestus, hun sang med, for en rådsforsamling i Frelsens Hær. I Die Maßnahme er det således ikke bare kommunisternes beretning, men gennem deres spil også en række gestus hos den kammerat, de gik frem mod, der bliver bragt for partitribunalet. Hvad der det episke drama overhovedet er et kunstmiddel af subtileste art det ep særligt tilfælde, til et kunstmiddel bliver i lærestykket, der er et særligt tilfælde, til et kunstmiddel for de nærmeste formål. I øvrigt er det episke teater per definition gestisk. For jo tiere, vi afbryder en handlende, desto flere gestus får vi.

\section{Lærestykket}

Det episke teater er i hvert fald fuldt så vel tiltænkt de spillende som tilskuerne. Lærestykket skiller sig i det væsentlige ud derved, at det på grund af apparatets særlige fattigdom forenkler og opfordrer til publikums udveksling med aktørerne og aktørernes med publikum. Hver tilskuer vil kunne blive medspiller. Og faktisk er det nemmere at spille "læreren" end „helten“.

I den første version af Lindberghfluges, der blev offentliggjort i et magasin, figurerede flyveren endnu som helt. Den var tiltænkt hans forherligelse. Den anden version skylder sin tilblivelse - og det er oplysende - en selvjustering fra Brechts side. Hvilken begejstring gik der ikke gennem de to kontinenter i dagene efter 
denne flyvning. Men den futtede af som sensation. Brecht bestræber sig i Flug der Lindberghs på at analysere "oplevelsens" spektrum for at afvinde det „erfaringens" farver. Den erfaring, der kun kunne øses af Lindberghs arbejde, ikke af publikums sindsbevægelse, og skulle tilføres "Lindbergherne".

Da T. E. Lawrence, forfatteren af Visdommens syv søjler, sluttede sig til flyvetropperne, skrev han til Robert Graves, at dette skridt for nutidens menneske var, hvad det for middelaldermennesket havde været at gå i kloster. I denne udtalelse genfinder man den buespænding, der kendetegner Flug der Lindberghs, men også de senere lærestykker. En klerikal strenghed anvendes på undervisningen i en nutidig teknik - her den i flyvevæsenet, senere den i klassekampen. Denne anden anvendelse er mest omfattende udformet i Moderen. Det var dristigt at holde netop et socialt drama frit for de virkninger, som indfølingen medfører og dets publikum var så vant til. Det ved Brecht; han siger det i et brevdigt, han i anledning af stykkets opførelse i New York stilede til den derværende arbejderscene: „Nogle spurgte os: Vil arbejderen også forstå jer? Vil han give afkald på den vante rusgift, deltagelsen - $i$ ånden - $i$ fremmed harme, i de andres opstigning; på al den illusion, der oppisker ham i to timer og efterlader ham mere udmattet, fyldt med vag erindring og vagere håb?"

\section{Skuespilleren}

Det episke teater rykker, og det kan sammenlignes med filmstrimlens billeder, frem i stød. Dets grundform er chokket, hvormed stykkets enkelte, vel adskilte situationer støder mod hinanden. Songs, plakattekster, gestiske konventioner adskiller den ene situation fra den anden. Således opstår der intervaller, som snarest indskrænker publikums illusion. De lammer dets indfølingsberedskab. Disse intervaller er forbeholdt dets kritiske stillingtagen (til personernes fremstillede adfærd og måden, den fremstilles på). Hvad fremstillingsmåden angår, så er skuespillerens opgave i det episke teater at vise i sit spil, at han holder hovedet koldt. Indføling er så at sige heller ikke anvendelig for ham. En sådan spillemåde er det dramatiske teaters "skuespiller" ikke altid og i alle henseender forberedt til. Ved hjælp af fo- restillingen om „teaterspil“ kan man måske mest fordomsfrit komme det episke teater nær.

Brecht siger: „Skuespilleren skal vise en ting, og han skal vise Brech. Han viser naturligt tingen ved at vise sig selv; og han viser sig selv ved at vise tingen. Skønt dette falder sammen, må det dog ikke falde sammen på en sådan måde, at forskellen mellem disse to opgaver forsvinder." Med andre ord: Skuespilleren skal forbeholde sig muligheden for med kunst at falde ud af rollen. I det givne øjeblik skal han ikke give afkald på at spille den eftertænksomme (den der tænker over sin rolle). Med urette ville eftertænksomme (den som Tieck for eksempel håndterer den i Den bestøvlede kat. Denne har ikke noget læremål; den viser i grunden kun forfatterens filosofiske informerethed, som under stykkeskrivningen hele tiden har for øje: Verden er vel i sidste ende også nok et teater.

Utvunget vil netop spillemåden på det episke teater lade det fremgå, i hvor høj grad den artistiske interesse på dette felt er identisk med den politiske. Man behøver bare at tænke på Brechts cyklus: Furcht und Elend des dritten Reiches. Det er let at indse, at opgaven at eftergøre en SS-mand eller et medlem af folkedomstolen måtte betyde noget fundamentalt andet for den eksilerede tyske skuespiller, den tilfaldt, end lad os sige opgaven at legemliggøre Moliéres Don Juan for en god familiefar. For førstnævnte kan indfølingen næppe betragtes som en egnet fremgangsmåde - ligesom der da for ham ikke vil kunne findes en indføling i hans medkæmpendes morder. En anden, distancerende modus kunne i sådanne tilfælde føre til en ny ret og måske et særlig vellykket resultat. Denne modus ville være den episke.

\section{Teatret på podiet}

Hvad det drejer sig om for det episke teater, er nemmere at definere ud fra begrebet scene end ud fra begrebet nyt drama. Det episke teater tager en omstændighed i betragtning, som man ikke har været tilstrækkelig opmærksom på. Den kan betegnes som tilkastningen af orkestra. Den afgrund, der skiller spillerne fra publikum som de døde fra de levende, den afgrund, hvis tavshed i skuespillet øger ophøjetheden, hvis lyden i operaen 


\title{
Benjamin og korrespondancerne
}

øger rusen, denne afgrund, der blandt alle teatrets elementer uudsletteligst bærer sporene af dets sakrale oprindelse, har mistet stadig mere i betydning. Endnu ligger scenen forhøjet. Men den stiger ikke længere op af et uendeligt dyb: den er blevet podium. Lærestykke og episk teater er et forsøg på at indrette sig på dette podium.

På dansk ved Karsten Sand Iversen

\author{
CHRISTOPHER PRENDERGaSt
}

Som de fleste ved, havde Benjamin en højtudviklet smag, ja ligefrem et genialt anlæg, for det aleatoriske. Mens han snusede sig frem til de mere dunkle afkroge og utilgængelige steder inden for modernitetens område, kunne han tilfældigvis, eller i hvert fald så det så ud som et tilfælde, snuble over netop den ting, som med garanti ville overraske en, som i kraft af sin chok-virkning får en til at stille spørgsmål eller etablerer en spørgende holdning og en ny bevidsthed om det fænomen undersøgelsen gælder. Dette er en integrerende del af den Benjaminske metode, en central komponent $i$ hans mikrologi, og på det punkt står han uden tvivl temmelig meget i gæld til den kontakt han havde med surrealisterne og deres interesse for det "fundne objekt" [l'objet trouve $]$ og for hvad André Breton (noget uigennemskueligt) kaldte for det "objektive tilfælde" [hasard objectif]. Hvad mere er, så finder man også i alliancen mellem det aleatoriske og det fragmentariske (hans fragmentariske skrivemåde) en af grundene til, at Benjamin er så svær at læse. Overraskelsen bliver ofte formidlet $i$ form af en logisk eller syntaktisk ellipse eller, endnu mere radikalt, helt uden medfølgende kontekstualisering overhovedet, præsenteret uden kommentar og så at sige omgivet af tavshed.

Det er ikke min hensigt at forsøge at efterligne Benjamins metode hér. Jeg nævner imidlertid dette, fordi det er relevant for mit emne på en måde vi skal se om et øjeblik. Emnet selv er velkendt: det er korrespondancerne, en doktrin og en praksis som i særlig grad bliver associeret med Baudelaire og som jeg i nogen grad ønsker at betragte i tilknytning til Benjamin (eller rettere sagt Benjamins forhold til disse) ved hjælp af en ligeledes velkendt, men samtidig notorisk vanskelig konstellation af begreber som 